\title{
Письма как художественный текст и политическое мастерство
}

\section{Letters as Literary Text and Political Artistry}

\author{
Ангелина Вачева \\ Софийский университет им. Св. Климента Охридского \\ Angelina Vacheva \\ Sofia University "St. Kliment Ohridski" \\ avacheva@slav.uni-sofia.bg
}

Kelsey Rubin-Detlev. The Epistolary Art of Catherine the Great. Liverpool: Liverpool University Press on behalf of the Voltaire Foundation, 2019, 416 p. ISBN 9781789620078

Огромное эпистолярное наследие Екатерины II труднее всего давалось ученым, и как объект публикации, и как объект исследования. Вплоть до нашего времени тысячи писем, написанных императрицей собственноручно или же под ее диктовку или по поручению, увидели свет еще в XIX веке на страницах исторических сборников и журналов. Многие еще дожидаются своих издателей в архивных хранилищах. Общеизвестна неудача, постигшая А. Н. Пыпина и его сотрудников в деле издания академического собрания сочинений Екатерины II: предназначенный для переписки шестой том так никогда и не был издан, в отличие от всех прочих произведений сиятельного автора в самых разнообразных жанрах. Даже после того, как в последние десятилетия появились основательные исследования екатерининского литературного наследия (сатирической и морализаторской прозы, литературных сказок, драматургии, автобиографии), эпистолярий императрицы ограничивался критическими изданиями и исследованиями переписки с отдельными корреспондентами, ${ }^{1}$ попытки охватить весь корпус ее писем не предпринимались.

Письма императрицы, также, как и ее автобиография, рассматривались до недавнего времени преимущественно как документы, проливающие свет на те или иные исторические события и процессы. Очень редко они интерпретировались как литературные тексты, а многие исследователи принимали за чистую монету слова Екатерины о том, что ее съедает мания графомании и что она не принимает всерьез свои литературные упражнения. Только в последние десятилетия Екатерина получила признание как русская и европейская писательница.

\footnotetext{
${ }^{1}$ См. В. С. Лопатин, Екатерина II и Г. А. Потемкин. Личная переписка (Москва: Наука, 1997); (V. S. Lopatin, Ekaterina II i G. A. Potemkin. Lichnaia perepiska (Moscow: Nauka, 1997); Voltaire and Catherine the Great, Voltaire - Catherine II: Correspondance 1763-1778, ed. Alexandre Stroev (Paris: Editions Non Lieu, 2006); Charles-Joseph de Ligne, Correspondances russes, eds. Alexandre Stroev and Jeroom Vercruysse. Vols. 1-2 (Paris : Honoré Champion, 2013); Catherine the Great and Friedrich Melchior Grimm, Une correspondance privée, artistique et politique au siècle des Lumières, vol.1. 1764-1778, ed. Sergei Karp (Moscow: Centre international d'étude du 18e siècle, 2016).
} 
Рецензируемая книга К. Рубин-Детлев ставит себе целью раскрыть мастерство Екатерины II как автора писем. Интерес исследовательницы к эпистолярному наследию российской государыни зарождается еще в студенческие годы, когда она защищает последовательно бакалаврскую и магистерскую работы о переписке Екатерины II и Вольтера и литературном салоне Екатерины II. ${ }^{2}$ Наиболее полно этот интерес реализовался в докторской диссертации К. Рубин-Детлев “The Letters of Catherine the Great and the Rhetoric of Enlightenment," защищенной в Оксфорде в 2016 г. под руководством Э. Кана. Этот труд и лег в основу рецензируемой книги. Само включение ее в престижную серию Oxford University Studies in the Enlightenment (Voltaire Foundation), продолжившую знаменитые Studies on Voltaire and the Eighteenth Century, говорит о достоинствах как исследовательского подхода, так и подведенных итогов. Путь к книге лежал также через участие в переводе избранной корреспонденции Екатерины II (совместно с Э. Каном) ${ }^{3}$ и в проекте дигитализации эпистолярного наследия императрицы CatCor: The Correspondence of Catherine the Great. ${ }^{4}$ Накопленный опыт сказался в разностороннем подходе автора к предмету исследования. В работе видна также забота о читателе: к его великой радости цитаты из писем Екатерины II даются как в переводе на английский язык, так и в оригинале на французском, русском и немецком языках.

Вне всякого сомнения, и в выборе темы, и в объеме текстового материала проявляется амбициозность и смелость молодого автора. Главная задача исследования - проследить формирование уникального авторского эпистолярного стиля Екатерины II как одного из выдающихся представителей европейского Просвещения. Формулируя цели своего труда, К. Рубин-Детлев присоединяется ко всем тем исследователям, которые в последние два-три десятилетия стараются "подвергнуть переоценке место, которое Екатерина, ключевая фигура всех аспектов российского Просвещения, стремилась занять в интеллектуальном и культурном ландшафте своего времени" (p. 7). Свою концепцию автор строит на основании писем императрицы европейским и русским адресатам, написанных преимущественно в годы ее активного присутствия у власти. Этот огромный корпус насчитывает между 10 и 11 тысяч посланий, адресованных как минимум 220 лицам (р. 13). В центре внимания исследовательницы находятся как автографы, так и письма, написанные секретарями императрицы под ее диктовку или же по ее указанию, но просмотренные и подписанные ею, и иногда, как знак особого внимания к адресату, снабженные собственноручной припиской.

К. Рубин-Детлев подходит к переписке Екатерины II как к своего рода эгодокументу. По ее мнению, “в каждом письме Екатерина оставляет свой собственный текстуальный образ,” а также “адаптирует этот образ к адресату,

\footnotetext{
${ }^{2}$ Kelsey Rubin-Detlev, "The Correspondence between Voltaire and Catherine II: An Analysis of Literary Role-Play" (PhD diss., The University of Oxford, 2016); Kelsey Rubin-Detlev, "Diderot, Derzhavin, and the Salon of Catherine II: Case Studies on the Integration of Russia into the Republic of Letters" (M.A. diss., Columbia University 2012).

${ }^{3}$ Catherine the Great, Catherine the Great: Selected Letters, trans. and eds. Andrew Kahn and Kelsey Rubin-Detlev (Oxford: Oxford University Press, 2018).

4 "CatCor: The Correspondence of Catherine the Great," The University of Oxford, accessed 10.10.2020, http://catcor-dev.oucs.ox.ac.uk.
} 
согласно своим целям в каждой ситуации” (р. 9). В посланиях императрицы автор видит род дневника, в котором день за днем та представляет себя. В то же время они представляют собой самостоятельную литературную ценность, в которой эпистолярное $Я$ формируется под влиянием жанровых конвенций и возможностей. Рубин-Детлев рассматривает письма Екатерины II не как застывшие и неизменные факты, а как процесс, как рабочие документы, в которых императрица старательно лепит свой образ, иногда с иронией, но никогда вполне откровенно, с учетом личности адресата, цели письма и с мыслью о будущих читателях, когда послания будут опубликованы. Во вступлении (p. 1-32) комментируются наиболее крупные массивы писем, адресованные избранным собеседникам. Особое внимание уделяется хронологическим рамкам екатерининской корреспонденции (от наиболее ранних сохранившихся писем 1742 г. до последних, написанных перед смертью). Перечисляются также этапы эпистолярного творчества государыни (юношеские письма и написанные до восшествия на престол, письма 1760-х гг., когда устанавливаются связи с philosophes, 1770-е гг. (являющиеся переходным этапом в екатерининской эпистолографии), новые тенденции 1780-х и поздние письма 1790-х годов, в которых сильно меняются авторский стиль и тематика под влиянием Французской революции (р. 10-11). Необходимо отметить, что автор работала с множеством архивных источников, ${ }^{5}$ преимущественно в западноевропейских архивах, сравнив опубликованные тексты с оригиналами.

На основе современного подхода в изучении эпистолярного наследия XVIII века, представленного в работах Бернара Брэ и его последователей, рассматривающих переписку людей, занимающих высокие позиции в обществе как корпус текстов, не поддающихся привычному делению на приватные и публичные, К. Рубин-Детлев определяет письма русской государыни как безусловно публичные. Это создает, по ее мнению, уникальную ситуацию, продиктованную статусом Екатерины II как монарха, представлявшего российскую нацию (р. 17). Другой ключевой подход, сформулированный во вступлении, это гендерный, рассматривающий выражение женского $Я$ автора писем. Особое внимание также уделено стремлению императрицы стать ведущей фигурой в элитарном философском диалоге Просвещения. ${ }^{6}$

Первая глава "Catherine the Epistolarian” (p. 33-84) логично посвящена проблеме формирования и продолжавшейся на протяжении всей ее жизни эволюции авторского стиля писем Екатерины II, а также созданию и культивированию корреспондентских сетей императрицы в изменяющихся общественных и политических условиях. В хронологическом порядке в главе рассмотрены этапы формирования эпистолярного $Я$ автора писем. Первый этап (1742-1762) - это обучение юной принцессы Софии-Фредерики Ангальт-Цербстской правилам корреспонденции под руководством ее воспитателей и под влиянием ее матери,

\footnotetext{
5 К. Рубин-Детлев отмечает прочтение около ста неопубликованных писем, хранящихся в Штутгарте, Вольфенбюттеле, Вене (12).

${ }^{6}$ Это и есть, на мой взгляд, также главная идея екатерининской автобиографии. См. Ангелина Вачева, Потомству Екатерина II. Идеи и нарративные стратегии в автобиографии императрицы (София: Университетско издательство “Св. Климент Охридски,” 2015) (Angelina Vacheva, Potomstvu Ekaterina II. Idei i narrativnye strategii v avtobiografii imperatritsy (Sofia: Universitetsko izdatel'stvo "Sv. Kliment Okhridski," 2015), особенно книгу II “Проблема 'просвещенного монарха' в автобиографии императрицы Екатерины II," 303-564.
} 
герцогини Иоанны-Елизаветы. Ценны и интересны наблюдения К. Рубин-Детлев о том влиянии, которое мать, горячая поклонница эпистолярия г-жи де Севинье, корреспондентка Вольтера, приятельница Готшеда и завсегдатай салона мадам Жоффрен, имела на формирование вкуса своей дочери. Эти выводы были бы еще убедительнее, если бы для сравнения был привлечен автобиографический контекст. В различных редакциях своей автобиографии Екатерина II, в своем стремлении представить себя как «self-made woman», сначала преуменьшает, а потом и вовсе показывает в отрицательном свете роль своей матери, которая представляется как соперница, вредящая своей дочери, ${ }^{7}$ несмотря на то, что переписка между ними не прекращалась до смерти герцогини. Впрочем, главный упрек, который можно предъявить к автору рецензируемого труда, и состоит в чрезвычайно редком и недостаточном обращении к автобиографическому материалу. Сосредоточенность исключительно на переписке может быть оправдана в диссертационном тексте, имея ввиду объем исследуемого материала. В книге же, предназначенной гораздо более широкой научной (и не только!) аудитории, небольшие отсылки к интерпретации соответствующих эпизодов, жизненных ситуаций и отношений в автобиографии Екатерины II, внесли бы дополнительные нюансы в точные и основательные наблюдения автора. В письмах, также как и в автобиографии императрица старательно и стратегически обдуманно создает свой образ. Письма (и, по всей вероятности, устные рассказы) во многих случаях служили ей своеобразной “лабораторией.” И в мемуарном тексте, и в письмах, как это показывает К. Рубин-Детлев, образ автора не застывший, а динамичный и меняющийся, нарушающий стереотипы, следующий собственной идеологии. Исследовательница убедительно доказывает, что будущая великая княгиня, которая, согласно мемуарному рассказу, познакомилась с письмами мадам де Севинье в России, знала их задолго до своего отъезда из родного дома, именно благодаря своей матери. Эпистолярный стиль а̀ la Mme Sevigné со свойственной ему игрой, сменой масок, нарочитой небрежностью и разговорностью, как это показано в книге, станет основанием собственного эпистолярного стиля Екатерины II. Следующим наставником в искусстве писать письма (и в политике) будет английский посол в Петербурге граф Чарльз ГенбуриУильямс. Тайная переписка с ним (1756-1757) станет настоящей школой дипломатии и политической хитрости для молодой великой княгини, которая, соблюдая наложенные Елизаветой Петровной правила, переписывала изготовленные канцелярией письма к родным, но находила при этом способы вести корреспонденцию с Уильямсом, Понятовским, матерью, З. Чернышевым. В этот период ученичества, по мнению исследовательницы, несмотря на запрет вести личную корреспонденцию, юная принцесса следует устоявшимся образцам аристократического эпистолярного общения (р. 47). Все же, думаю, можно было уделить несколько больше внимания письмам юной Екатерины отцу, а также юношеской “философической” переписке с графом Гюлленборгом и письмам

\footnotetext{
${ }^{7}$ Об использовании романной топики в этом эпизоде см. Ангелина Вачева, Потомству Екатерина II, 126-1зо. О том, что Екатерина II осознавала настоящую роль матери в своей жизни см. Клаус Шарф, Екатерина II, Германия и немцы (Москва: Новое литературное обозрение, 2015), 74. (Klaus Sharf, Ekaterina II, Germaniia i nemtsy (Moscow: Novoe literaturnoe obozrenie, 2015), 74.
} 
мадмуазель Кардель, в которых видны черты будущего крупного игрока на европейской дипломатической и интеллектуальной сцене.

Следующий важный период в истории Екатерины-мастера эпистолярного жанра, который подробно комментирует К. Рубин-Детлев, это первая часть ее царствования (1762-1774). Это время отмечено утверждением императрицы на престоле, ее дебютом в качестве основного действующего лица международной политики и вхождением в пан-европейскую интеллектуальную и политическую элиту (р. 48). Главное завоевание Екатерины II в этот период с точки зрения рассматриваемой темы - это установление корреспондентской сети с разнообразными кругами европейского общества. В первую очередь это переписка с философами Просвещения и близкими к ним интеллектуальными и светскими кругами - Вольтером, Д’Аламбером, г-жой Жоффрен, Мармонтелем, Фальконе (служащим также посредником в общении с Дидро), а также с коронованными особами Европы - Фридрихом II и его братом принцем Генри, Густавом III, Станиславом Понятовским (уже не любовником, а королем польским и ее ставленником), Марией-Терезией и Иосифом II. Третий круг составляют члены семьи и близкие к ней люди, самым известным персонажем которого является гжа Бьелке. Что же касается русских корреспондентов, помимо чисто деловой переписки, это в первую очередь, сановники, военные деятели, секретари, такие как А. Олсуфьев, Н. Панин, А. Орлов. Рубин-Детлев отмечает отсутствие писем фаворитам Г. Орлову и А. Васильчикову. Она анализирует “чрезвычайно большое число ролей” и способность императрицы адаптироваться ко вкусам, интересам, понятиям, любопытству собеседников как следствие обретенной полной свободы эпистолярного общения. Умение воспользоваться всеми этими контактами для “рекламных" целей своей политики и личности является характерной чертой эпистолярного искусства государыни.

Следующий “переходный” (p. 56) этап (1774-1781), по мнению исследовательницы, приходится на время, когда Екатерина II, преодолев ряд испытаний во внешней и внутренней политике, почувствовала себя уверенно на троне. Это эпоха после окончания Русско-турецкой войны 1768-1774 гг. и Пугачевщины, когда императрица уже приобрела имидж реформатора и законодательницы. Перемена направления во внешней политике с отказом от „Северной системы“ Панина и стремлением полностью освободиться от его влияния сказывается на содержании ее писем. Период отмечен серьезным изменением в корреспондентских связях Екатерины II после смерти Вольтера и гжи Бьелке, а также прекращения переписки с г-жой Жоффрен и Д’Аламбером. В то же время на смену этим влиятельным корреспондентам приходит наиболее доверенное лицо русской императрицы, Ф.-М. Гримм. После возвращения Дидро из Петербурга во Францию, философ продолжал поддерживать ее позитивный образ, несмотря на то, что он смотрел на российскую реальность без иллюзий. ${ }^{8}$ Рассказы о Екатерине, основанные на личных впечатлениях Дидро, которые распространялись по Парижу, вызвали всплеск интереса к ее письмам. Послания императрицы, которые и до того вызывали широкий интерес, стали притягивать еще больше внимание не только парижского бомонда, но и полиции (р. 57).

\footnotetext{
${ }^{8}$ Об отношении Дидро к России и его сочинениях на русскую тему см. С. А. Мезин, Дидро и цивилизация России (Москва: Новое литературное обозрение, 2018). (S. A. Mezin, Didro i tsivilizatsiia Rossii (Moscow: Novoe literaturnoe obozrenie, 2018).
} 
Внимание автора книги привлечено также к переписке императрицы с королем Швеции Густавом III и с такой крупной фигурой в государственных делах и личной жизни императрицы, каким был Григорий Потемкин.

Как время “мастерства” (р. 61) характеризует Рубин-Детлев следующий период, который продолжался с 1781 по 1789 г. Тогда, по ее мнению, Екатерина II, находясь в зените своего интеллектуального могущества, реформирует Россию, утверждает свое политическое влияние в Европе и обретает максимальный контроль над своими эпистолярными связями, в центре которых безусловно находится переписка с Гриммом и Потемкиным. Среди других выдающихся корреспондентов Екатерины II автор называет австрийского императора Иосифа II, д-ра ИоганнаГеорга Циммерманна, принца Шарля-Жозефа Де Линя, Элизу фон дер Рекке. В России ведущее место среди ее адресатов занимают сановники - А. Безбородко, П. Еропкин и Я. Сиверс. Сочетание политики и личных привязанностей, широких культурных интересов и инициатив, полемика с внутренними и внешними оппонентами, все это резюмировано с достаточной полнотой в этой части книги.

Последний этап в жизни Екатерины II и как человека, и как автора писем (17891796) рассматривается под знаком переживаемого государыней кризиса, вызванного Французской революцией. Разрушение старого мира подвергло испытанию образ Северной Минервы как просвещенного монарха. Очередная Русско-турецкая война, серия дипломатических поражений, раздел Польши, натянутые отношения с Пруссией и Швецией поставили на кон авторитет российской императрицы. Французские события, трагическая судьба королевской семьи, потеря политических партнеров (Густава III, Иосифа II, Потемкина), сужение круга доверенных корреспондентов становятся причиной тревог и влияют на содержание и стиль екатерининских писем.

Первая глава заканчивается характеристикой эпистолярной географии Екатерины II и интереснейшим сравнением литературных занятий, стиля и тематики писем русской императрицы и ее западноевропейских “коллег” Фридриха Великого и Марии-Терезии. Соревнование Фридриха II и Екатерины II в привлечении общественного мнения Европы, использование собственного литературного творчества в политических целях сказываются и на соперничестве обоих монархов в эпистолярных контактах с выдающимися умами Просвещения. Однако, переписка русской монархини и эпистолярий австрийской императрицы мало похожи. В последнем преобладают контакты с семьей и, главным образом, с многочисленными детьми Марии-Терезии, вопросы религии и благочестия, т.е. темы, гораздо менее характерные для русской государыни. Наблюдения над сетью эпистолярных контактов Екатерины II проиллюстрированы серией карт, которые наглядно представляют динамику переписки императрицы в вышеназванные периоды.

Вторая глава "Catherine the Great and Eighteenth-Century Epistolary Style" (p. 85133) посвящена собственно “технике” екатерининских писем. Последовательно рассматриваются проявления гендерных аспектов и стремление к созданию хорошо обдуманного собственного образа ("self-fashioning"), в котором сочетаются “мужские" и “женские” качества. Стиль Екатерины сочетал следование эпистолярному этикету XVIII века, представленному в многочисленных руководствах, с известными отклонения от него в стиле г-жи де Севинье. К. РубинДетлев анализирует различные типы писем (письмо-совет, галантное письмо, 
семейная переписка, любовные письма, “нарративные” письма, описывающие конкретные обстоятельства или события) ${ }^{9}$ и их частое смешение в эпистолярии Екатерины. Автор книги отмечает на редкость небольшой круг семейных контактов русской правительницы. В то же время ее действительные родственные связи с большинством европейских монархов становятся скорее риторической фигурой в корреспонденции с Фридрихом Великим и Густавом III. Стиль светского салонного общения, вариативность выбора лексики в зависимости от адресата и ситуации, вплоть до имитации низовой фольклорной речи в русских письмах, использование пословиц - все это знаки авторской индивидуальности императрицы. Комментируя переписку Екатерины с Гриммом, К. Рубин-Детлев уделяет внимание эпистолярной игре со ссылками на популярные романы (Тристрам Шенди Стерна, Жак-фаталист Дидро). Исследовательница считает, что в своих “нарративных" письмах Екатерина II использует жанр портрета, включая и описания происшествий и знаменательных событий. Можно только пожалеть о том, что, комментируя этот интереснейший материал, она не остановилась подробнее на прозвищах, которыми Екатерина и Гримм наделяли монархов и политических деятелей, и на особом использовании немецких фраз, которые эти два немца вкрапливали во французский текст своих писем, чтобы придать своим рассуждениям особую пикантность. В эпистолярной игре с Гриммом, отличающейся нарочитой фамильярностью, следует особо отметить маску буржуазки. ${ }^{10}$ Автор комментирует риторические функции другой важной стилистической особенности эпистолярного стиля Екатерины II, возникшей под влиянием аристократической салонной культуры, le style coupé, который имитировал недосказанность спонтанной речи. Сочетание стилистики в духе мадам де Севинье со вкусом к приемам драмы также является отличительной чертой екатерининских посланий.

Комментарий любовных писем сосредоточен на ранней переписке молодой великой княгини с графом Захаром Чернышевым и с Потемкиным. В письмах Чернышеву эпистолярный стиль находится под сильным влиянием рекомендаций письмовников. ${ }^{11}$ В письмах Потемкину с полной силой проявляется протеизм таланта императрицы (р. 127-131). В них представлен широкий стилистический

\footnotetext{
${ }^{9}$ Например, письмо Вольтеру с описанием Чесменской битвы от 16/27.09.1770, созданное в свою очередь на основе письма Алексея Орлова.

10 К подобной "маске“ Екатерина прибегает и в автобиографии, скрывая за интертекстом эпистолярного (sic!) романа г-жи Риккобони “Письма мисс Фанни Батлер” рассказ о любовных отношениях с Сергеем Салтыковым. См. Ангелина Вачева, "Не судите обо мне как о других женщинах.": Мемуары Екатерины II и “Письма мисс Фанни Батлер” г-жи Риккобони (Москва: Новое литературное обозрение, 80, 2006), 111-130; (Angelina Vacheva, "Ne sudite obo mne o drugikh zhenshchinakh:" Memuary Ekaterniny II i "Pis'ma miss Fanni Batler" g-zhi Rikkoboni (Moscow: Novoe literaturnoe obozrenie, 8o, 2006, 111-13о. См. также Вачева, Потомству Екатерина II, 233-271. (Vacheva, Potomstvu Ekaterina II, 233-271).

" Помимо проблем стилистики, недавно внимание аудитории привлекла интерпретация цикла писем к Чернышеву историком Марией Крючковой. На основе содержания этих писем исследовательница считает Чернышева, а не Сергея Салтыкова первым любовником великой княгини. Крючкова полагает, что граф был отцом тайной побочной дочери Екатерины, родившейся в конце 1755 г. и воспитывавшейся в семье верного слуги императрицы Василия Шкурина и носившей имя Марии, впоследствии фрейлины, в конце жизни принявшей постриг под именем инокини Павлы (М. А. Крючкова, Мемуары Екатерины II и их время (Москва: Летний сад, 2009), 195-196). (M. A. Kriuchkova, Memuary Ekateriny II i ikh vremia (Moscow: Letnii sad, 2009), 195196).
} 
диапазон, от изысканного французского до разговорного русского языка, иногда с элементами фольклора. В них серьезный деловой тон соседствует с игровым. Главный вывод исследовательницы состоит в том, что императрица редко писала “чистые" галантные письма, но часто смешивала черты различных типов посланий, пользуясь всем арсеналом литературной культуры, игрой, сменой гендерных ролей, но сохраняя при этом контроль над собой (р. 132).

Создание образа интеллектуала на троне, “нового Марка Аврелия” - предмет третьей главы "Fashioning the Great Enlightenment Monarch" (p. 135-183). Реминисценции из другого эмблематичного романа - мармонтелевского Велизария - дополняют ее портрет просвещенной правительницы (p. 152). Французские короли Генрих IV и Людовик XIV представлены как герои на поле

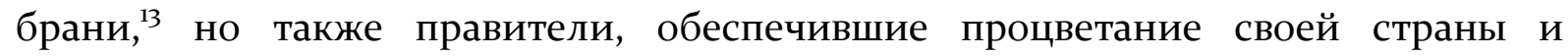
покровительствовавшие наукам и искусствам, и выступают в переписке императрицы как образцы для подражания. По мнению К. Рубин-Детлев, в создании собственного образа просвещенного монарха, Екатерина II ориентируется на доминанты в государственной деятельности каждого из этих великих мужей. Специфическая гендерная игра в переписке Екатерины II отражает новые представления о величии и славе, сформулированные энциклопедистами, которые отрицали, что славу можно приобрести единственно на поле брани. В посланиях европейским корреспондентам императрица подчеркивает свою роль военачальника, в конечном счете принимающего главные решения в ведении военных действий. В то же время, это редкое для женщины XVIII столетия положение сочетается в личности государыни с другой мужской претензией - быть интеллектуалом на троне и законодателем.

В этой связи было бы уместно прокомментировать здравый практический смысл русской императрицы в ответ на славословия философов, особенно Вольтера. Автор труда отказывается от традиционного прочтения корреспонденции Вольтера и Екатерины во время Русско-турецкой войны 17681774 г., оставляя без внимания цели русского наступления в Средиземноморье и вольтеровскую идею освобождения Греции - колыбели цивилизации. Образ врага в лице Оттоманской империи, который неизменно обсуждается в работах, посвященных этой теме, лишь слегка затронут. ${ }^{14}$ Акцент в анализе делается на образе Екатерины-миротворицы, стремящейся прекратить кровопролитие и гибель невинных людей. Облик создательницы экономического благосостояния огромной империи послевоенного периода присутствует в переписке государыни во время Крымского путешествия. Другая черта образа просвещенной правительницы как сторонницы веротерпимости рассмотрена на примере писем, написанных во время путешествия по Волге.

Особое внимание уделяется в книге стремлению недавно взошедшей на российский престол императрицы привлечь на свою сторону философов

\footnotetext{
12 Уместно было бы, на мой взгляд, привести параллели с интерпретацией этих мотивов в автобиографии.

${ }^{13} \mathrm{O}$ значении образа Генриха IV в автобиографии Екатерины II см. Monika Greenleaf, "Performing Autobiography: The Multiple Memoirs of Catherine the Great (1756-1796)," The Russian Review, 63 (July 2004): 407-426.

${ }^{14}$ Все же желательно, чтобы читателю была предложена более подробная библиографическая справка, в которой, помимо книги А. Зорина, были бы указаны также работы А. Строева, И. Клейна и др.
} 
Просвещения, в частности, письмам к Д’Аламберу и Вольтеру и хозяйке престижного парижского салона г-же Жоффрен и, позднее, ее дочери, маркизе Ферте-Эмбо, ${ }^{15}$ и попыткам Екатерины с их помощью создать свой позитивный образ в глазах западноевропейской (прежде всего, французской) аудитории. Исследовательница отмечает использование Екатериной II в письмах жанра шутливой светской беседы, мотива дамской болтовни, комических масок невежды, педанта, эксцентрика; оценивает высокое значение веселости и смеха в литературном творчестве и быту императрицы. ${ }^{16}$ Автор подчеркивает значение для Екатерины атмосферы аристократической беспечности, галантного общения, веселья, которые императрица стремилась поддерживать в своем узком кругу, и которая проявляется в ее частных письмах. К. Рубин-Детлев удачно определяет эту особенность посланий Екатерины II как “виртуальный салон” (р. 112). Ирония и самоирония, ${ }^{17}$ завуалированная лесть, иногда гипербола и гендерная игра в соблазнение - эпистолярное “оружие” государыни, проявляющееся в переписке с Вольтером и мадам Жоффрен, но также и в письмах Фридриху Великому и Густаву III. Высоко оценивая качество проведенных автором наблюдений, все же думаю, что следовало бы учесть работы Татьяны Акимовой по этому вопросу. ${ }^{18}$

Четвертая глава “The Play of Authority in Epistolary Form” (p. 185-261) преподносит читателю настоящий сюрприз. Главный предмет анализа в ней - материальная форма екатерининских писем. К. Рубин-Детлев предлагает не только анализ мастерского использования Екатериной II вариативности словесных форм и ее умения удачно подобранной словесной формой укреплять и поддерживать свой авторитет, но также ее способности сочетать это с оформлением своих посланий. В этой части работы последовательно анализируются различные аспекты эпистолярного этикета с точки зрения вида и марки использованной бумаги, размещения текста письма, вида восковой печати и т.п. Так, учитываются размеры

\footnotetext{
${ }^{15}$ В связи с этим сюжетом см. недавнюю статью: А. Д. Ивинский, "Екатерина II, Е. Р. Дашкова и маркиза Ферте-Эмбо: о французских контекстах “Общества незнающих ежедневной записки,” Известия РАН. Серия литературы и языка, 79 (2020): 99-107. (A. D. Ivinskii, "Ekaterina II, E. R. Dashkova i markiza Ferte-Embo: o frantsuzskikh kontekstakh "Obshchestva neznaiushchikh ezhednevnoi zapiski," Izvestiia RAN. Seriia literatury i iazyka, 79 (2020): 99-107).

${ }^{16}$ Позволю себе напомнить, что ранние редакции екатерининской автобиографии написаны в форме письма к С.-А. Понятовскому, графине Брюс и барону А. И. Черкасову, которому мемуаристка обещает “извлекать ежедневно по крайней мере один взрыв смеха, или же спорить с ним с утра до вечера, потому что эти два удовольствия для него равносильны, я же люблю доставлять удовольствия своим друзьям." См. Екатерина II, Записки императрицы Екатерины Bторой (Санкт-Петербург: Издание А. С. Суворина. 1907), 73. (Ekaterina II, Zapiski imperatritsy Ekateriny Vtoroi (St. Petersburg: Izdanie A. S. Suvorina, 1907), 73). Камер-фурьерские журналы засвидетельствовали ежедневное присутствие, за крайне редкими исключениями, на протяжении многих лет этого персонажа за собственным столом императрицы.

${ }^{17}$ Интересно отметить, что это качество, столь свойственное переписке Екатерины II, крайне редко проявляется в ее автобиографии!

${ }_{18}$ Т. И. Акимова, Роль литературного творчества Екатерины II в становлении дворянского самосознания конца XVIII - начала XIX века (Саранск: Издательство Мордовского университета, 2013); (T. I. Akimova, Rol' literaturnogo tvorchestva Ekateriny II v stanovlenii dvorianskogo samosoznaniia kontsa XVIII --XIX veka (Saransk: Izdatel'stvo Mordovskogo universiteta, 2013); Т. И. Акимова, “Литературное творчество Екатерины II: “Галантный диалог“ в системе авторских стратегий (истоки, функции, жанры)" (Дисс. на соискание уч. степени доктора филологических наук, ИМЛИ, 2015). (T. I. Akimova, "Literaturnoe tvorchestvo Ekateriny II: "Galantny dialog" v sisteme avtorskikh strategii (istoki, funktsii, zhanry)" (Diss. na soiskanie uch. stepeni doktora filologicheskikh nauk, IMLI, 2015).
} 
бумажных листов, использованных для официальных писем и частных посланий, записок.

Предметом комментария становятся и паратексты екатерининских писем: обращения, формулы вежливости для начала и конца письма, подпись, датировка (аккуратность даты или же многочисленные приписки). Особенно ценны наблюдения над гендерными маркерами в письмах Екатерины II, когда императрица имеет в виду свою роль главы государства (например подпись Allié Alliée/ “союзник” вместо “союзница” / м.р. vs ж.р., с. 222-223). В обращениях, в заключительных формулах и подписи, оказывается, также может проявиться самоирония и шуточное дружеское отношение к корреспонденту, как это происходит в переписке с Гриммом. Соблюдение или же нарушение установленного этикета - знак отношения к адресату. Второе может подтверждать благорасположение, дружеское отношение к получателю письма, притом, что императрице всегда удавалось сохранить нужную дистанцию и свой авторитет. Особо подчеркивается значение использования русского этикета при обращении с русскими корреспондентами государыни (“матушка,” “батинька” / “батюшка,” р. 229), как средства создания доверительных отношений между правителем и подданным или же с фаворитами, как в случае с Потемкиным. Исключительно интересен анализ отношений Екатерины II и Фридриха II с их “учителем" Вольтером, на основании особенностей эпистолярного этикета. ${ }^{19}$ Исследовательница отмечает умелое использование таких инструментов, как постскриптумы или просто собственноручные приписки к деловым документам. Особое значение имели также адреса на конверте: строгое соблюдение стандарта адресования в заграничных посланиях и вариативность в зависимости от степени официальности повода письма в русской переписке, причем даже в надписи на конверте иногда имела место шутка, как в случае с письмом, выражавшим Державину благодарность за Фелицу (р. 254-255). ${ }^{20}$ Важную “рекламную роль” имели дорогие подарки (книги, табакерки, картины, эстампы, чай, кедровые орехи, меховые шубы и пр.), которые императрица посылала избранным корреспондентам. $^{21}$ Содержание этой части богато иллюстрировано фотографиями екатерининских автографов.

\footnotetext{
${ }^{19}$ O соперничестве с Фридрихом Великим и стремлении Екатерины II быть независимой от учителя см. скрытую дискуссию в автобиографии по поводу Анти-Макиавелли Фридриха в: Вачева, Потомству Екатерина II, 353-382. (Vacheva, Potomstvu Ekaterina II, 353-382).

${ }^{20}$ Не надо забывать, что эта ода Державина и интерпретация образа самой Екатерины-Фелицы стала символом нового политического и культурного дискурса в начале $1780-\mathrm{x}$ гг., направленного на сближение монарха и дворянской элиты. См. А. Д. Ивинский, Литературная политика императрицы Екатерины II: журнал “Собеседник любителей российского слова" (Москва: Книжный дом “Либроком,” 2012). (A. D. Ivinskii, Literaturnaia politika imperatritsy Ekateriny II: zhurnal "Sobesednik liubitelei rossiiskogo slova" (Moscow: Knizhnyi dom "Librokom," 2012).

${ }^{21}$ Эту практику негласной рекламы своей страны Екатерина II применяла, используя также корреспондентские сети своих приближенных и всячески помогала им найти нужные презенты. См. Ангелина Вачева, “Чай, пушени еленски езици и хайвер: Вкусните руски изкушения в писмата на Валентин Жамре-Дювал и Анастасия Соколова," в Дългият XVIII век: Наслади и забрани, ред. Рая Заимова, Надежда Александрова и Анна Алексиева (София: Българско общество за проучване на XVIII век, 2018), т. 2, 113-121. (Angelina Vacheva, "Chai, pusheni elenski ezitsi i khaiver: Vkusnite ruski izkusheniia v pismata na Valentin Zhamre-Diuval i Anastasiia Sokolova," v Dolgiiat XVIII vek. Nasladi i zabrani, red. Raia Zaimova, Nadezhda Aleksandrova i Anna Aleksieva (Sofia: Bulgarsko obshchestvo za prouchvane na XVIII vek, 2018), T. II, 113-121.
} 
В пятой главе "Epistolary Publicity and the Audience for Catherine's Correspondence” (р. 263-300) К. Рубин-Детлев рассматривает обстоятельства, в которых западноевропейская аудитория знакомилась с письмами русской императрицы. Налагая запрет на публикацию своих писем, Екатерина II рассчитывала преимущественно на их пересказ или публичное чтение в салонах. Автор считает, что императрица стремилась старательно управлять распространением своих посланий на Западе и направлять в желанную сторону общественное мнение, укрепляя свой авторитет, тогда как в России эта цель перед ней не стояла; она сама выступала гарантом авторитета своих подданных (р. 284). Исследовательница подчеркивает стремление Екатерины II связать воедино русскую и французскую аристократическую элиту. Она опровергает слухи о мнимом авторстве писем государыни. Автор вовсе не отрицает, что Екатерина II хотела, чтобы ее корреспонденция была позже опубликована, но считает, что, опасаясь осложнения политической ситуации, императрица оставляла эту возможность за потомством. К сожалению, автор книги не останавливается подробнее на драматической истории публикации переписки с Вольтером, осуществленной Бомарше в 1787 г., ${ }^{22}$ на рецепции других прижизненных изданий ее писем, например, переписки с д-ром Циммерманном.

Глава шестая “Greatness Contested: Catherine's Epistolary Response to the French Revolution” (р. 301-344) посвящена жизненному кризису, переживаемому Екатериной II во время Французской революции и стремлению всеми силами предотвратить крушение института абсолютной монархии и собственной системы ценностей, тщательно выработанной на протяжении ее правления. Активное обсуждение событий революции, поддержка роялистов, оживленная дипломатическая деятельность (и, соответственно, переписка), участие в заговоре для спасения королевской семьи ${ }^{23}$, все это отражается в переоценке прежних идеалов императрицы. Автор книги анализирует этот период как кульминацию екатерининской эпистолярной тактики, когда императрица использует свою корреспондентскую сеть в надежде найти наиболее широкий отклик. В первой половине 1790-х гг. меняется ее отношение к публикации собственных писем: в ней она видит возможность активной защиты своего дела. По мнению исследовательницы, противопоставление культуры Старого режима и новых республиканских манер и речевого этикета становится одной из основных тем в переписке с Гриммом (р. 321). Переживаемый кризис связан с переосмыслением образов «философов» - Вольтера, Руссо, Дидро. Террор во Франции и казнь Людовика XVI заставляют стареющую императрицу задуматься о еще более прочном союзе монарха и дворянства. Анализ екатерининских посланий времени Французской революции, предложенный К. Рубин-Детлев, позволяет объяснить смену авторских интенций в автобиографии. Императрица меняет жанровую концепцию мемуарного рассказа и задумывает позднейшую редакцию истории

\footnotetext{
${ }^{22}$ CM. Alexandre Stroev, "L'impératrice et le patriarche," Voltaire - Catherine II. Correspondance 1763-1778, 19-23.

${ }^{23}$ См. детальный анализ событий в: П. В. Стегний, “Прощайте, мадам Корф: из истории тайной дипломатии Екатерины Великой (Москва: Международные отношения, 2009). (P. V. Stegnii, "Proshchaite madam Korf: iz istorii tainoi diplomatii Ekateriny Velikoi (Moscow: Mezhdunarodnye otnosheniia, 2009).
} 
своей жизни как трактат о государе. Судить о достоинствах своей личности Екатерина II оставляет потомству.

Заключение/Conclusion: "New Readers and New Ways of Reading Catherine's Letters” (р. 345-352) традиционно подводит итоги исследования. Скрупулезный и многоаспектный анализ основных тенденций в переписке Екатерины II доказывает в очередной раз ее незаурядный литературный талант, проявившийся в неконвенциональных жанрах переписки и автобиографии, в которых $Я$ автора являет себя во всей своей полноте, но также изменчивости и эволюции.

В обширной библиографии к труду есть несколько знаковых лакун. Так, озадачивает отсутствие работ А. Ф. Строева, посвященных творчеству, политике и не в последнюю очередь эпистолярному наследию Екатерины II и издания текстов ее переписки под его редакцией. ${ }^{24}$ Вызывает удивление и отсутствие публикации переписки Вольтера и Екатерины II, подготовленной этим исследователем, включающей письма обоих корреспондентов, сверенные с оригиналами в русских и европейских архивах, исчерпывающую вступительную статью и детальный комментарий. ${ }^{25}$ Уместно было бы обращение к работам В. С. Люблинского, П. Р. Заборова, к переводу избранных писем Вольтера и Екатерины II на английский язык А. Лентина, ${ }^{26}$ и к книге Э. Кросса о Екатерине. ${ }^{27}$

Также неясно по каким причинам автор решает использовать то или другое издание переписки. Например, письма Екатерины II и Гримма цитируются по 23 номеру СИРИО (1878), тогда как 44 номер 1885 г. предлагает их расширенную публикацию с бо́льшим количеством текстов. То же можно сказать о втором дополненном издании перевода на английский язык переписки великой княгини Екатерины с Генбури-Уильямсом, к которому издатель Сергей Горяинов добавил письма С.-А. Понятовского. ${ }^{28}$ Выбор за исследователем, но его следует обязательно оговорить. Неприятное впечатление, на фоне общей скрупулезности работы, производит небрежность в поиске современных научных (а не научнопопулярных, какими являются добротные биографические труды О. Елисеевой о Екатерине II, бесспорно заслуживающие внимание широкой публики) исследований о литературном творчестве императрицы, появившихся в изобилии в последние годы. Современные технологии позволяют не только находить новые

\footnotetext{
${ }^{24}$ Из подготовленных под его редакцией изданий переписки Екатерины II в книге указано всего лишь издание "русской корреспонденции" принца де Линя, подготовленное совместно с Жеромом Веркрюисом (Charles-Joseph de Ligne, Correspondances russes), а из научных работ - статья Alexandre Stroev, "Friedrich Melchior Grimm et ses correspondants d'après ses papiers conservés dans les archives russes, 1755-1804," в La Culture française et les archives russes: une image de l'Europe au XVIII siècle, ed. Georges Dulac (Ferney-Voltaire: Centre international d'étude du XVIIIe siècle, 2004). Помимо многочисленных статей А. Ф. Строева, анализирующих переписку Вольтера и Екатерины II, переписку с Сенаком де Мельяном и другими французскими прожектерами, упомяну его недавно вышедшую книгу, предлагающую ценные и обширные наблюдения над сочетанием политических и дипломатических игр, с одной стороны, и литературы, с другой: Alexandre Stroev, La Russie et la France des Lumières: Monarques et philosophes, écrivains et espions (Paris: Institut des études slaves, 2017).

${ }^{25}$ Voltaire - Catherine II. Correspondance 1763-1778.

${ }^{26}$ Anthony Lentin, Voltaire and Catherine the Great: Selected Correspondence (Cambridge: The University of Cambridge Press, 1974).

${ }^{27}$ A. G. Cross, Catherine the Great and the British: A Pot-Pourri of Essays (Keyworth: Astra Press, 2001).

${ }^{28}$ Catherine the Great, Correspondence of Catherine the Great When Grand Duchess, with Sir Charles Hanbury-Williams and Letters from Count Poniatowski, ed. Earl of Ilchester (London: Thornton Butterworth, 1928).
} 
исследования, но, в случае недоступности определенных ресурсов, установить личный контакт с коллегами. Говорю это на основании личного опыта ученого, живущего и работающего в стране, в которой библиотечные фонды, связанные с XVIII веком, мягко говоря, не из самых богатых. Научная этика требует, чтобы авторы известных и широко распространенных суждений указывались. ${ }^{29}$ Случаи совпадения собственных наблюдений с мнениями, высказанными ранее другими исследователями, также следует отметить в ссылке.

Все эти замечания, однако, не уменьшают достоинства анализируемого труда. Надеюсь, что эти рекомендации пригодятся при возможном переиздании или переводе на русский язык. Исследование Рубин-Детлев является первым огромного эпистолярного наследия Екатерины Великой как единого корпуса и в дальнейшем, вне всякого сомнения, послужит основой многих будущих разысканий. Это важный и успешный шаг к реабилитации вклада русской императрицы в европейскую культуру как одного из ведущих интеллектуалов эпохи Просвещения.

\footnotetext{
${ }^{29}$ Речь идет, например, о высказанном Изабель де Мадариага мнении, что в поздний период своей жизни Екатерина II теряет многих своих сотрудников, корреспондентов, близких людей. См. И. де Мадариага, Россия в эпоху Екатерины Великой (Москва: Новое литературное обозрение, 2002), 569570. (I. de Madariaga, Rossiia v epokhu Ekateriny Velikoi (Moscow: Novoe literaturnoe obozrenie, 2002), 569-570). Или же о наблюдении А. Строева, о том, что императрица предпочитала отправлять Вольтеру письма обычной, а не дипломатической почтой, рассчитывая, что ее послания дойдут до западной аудитории благодаря перлюстрации (Voltaire-Catherine II, 19). Рубин-Детлев, впрочем, доказывает, что эта практика распространялась не только на корреспонденцию с Вольтером, но и на переписку с другими лицами и привлекала внимание соответствующих охранительных органов разных европейских стран.
} 